merich Czermak's political diary will also appear in the same series.

\title{
THE UNIVERSITY OF SALZBURG
}

The Historical Institute of the recently reinstituted University of Salzburg opened its doors to students in the fall semester of 1964-65. Several appointments were made for the new institute. Fritz Fellner, formerly a docent at the University of Vienna, was appointed professor of modern history. Heinrich Koller, docent at the Institut für Osterreichische Geschichtsforschung, in Vienna, was made professor of medieval history. Erika Weinzierl-Fischer was given a teaching post in Austrian history. Docent Wilvonseder was selected to teach ancient history and Library Director Forstner to give instruction in medieval Latin and paleography. At the end of the first school year 90 students were enrolled in the institute. In the field of modern history the library resources of the institute are being concentrated on the nineteenth and twentieth centuries.

\section{THE UNIVERSITY OF GRAZ}

\section{Lectures and Exhibits}

The most important historical event that recently occurred in Styria was the 1964 jubilee in honor of the beginning of the reign of Archduke Charles II of Inner Austria (1564-90), who became ruler after Emperor Ferdinand I's death. Archduke Charles, a moderate man but a decided Catholic and an energetic and successful ruler, accomplished as much that is exemplary in defending his lands (Styria, Carinthia, and Carniola) by fighting the Turks as he did for economic recovery and for culture, art, and learning. Famous musicians lived at his court at Graz. Charles II founded the University of Graz in 1585 . His state was the first one officially to introduce the improved Gregorian calendar.

The Province of Styria and its scientific institutes and art academies, provincial archive and library, academy of music, and, last but not least, its university worked with great zeal 